\title{
The Dachas of Russian Finland in the Cultural Landscape of the Baltic Coast of the First Third of the XX Century
}

\author{
Problems of Study, Preservation and Use*
}

\author{
Svetlana Levoshko \\ Scientific Research Institute of the Theory and History of Architecture and Urban Planning \\ Branch of the Central Institute for Research and Design \\ Ministry of Construction and Housing and Communal Services of the Russian Federation \\ St-Petersburg, Russia \\ E-mail: s_levoshko@mail.ru
}

\begin{abstract}
The article formulates the problems of research, promotion, preservation, and use of the dacha architecture of the Gulf of Finland within the boundaries of the Karelian isthmus. The features of the architectural and artistic identity of the cultural landscape of the Karelian isthmus, called "Russian Finland" in the Art-Nouveau era, are defined. They have been formed largely due to the summer housing and cultural domestic traditions as the result of fruitful cultural ties between Russia, especially St. Petersburg, and Finland at the turn of the XIX-XX centuries. The author emphasizes the urgent need to develop the special St. Petersburg program of conservation and use of dacha architecture, the rapid disappearance of the last best examples of which will lead to the disappearance of the unique layer of material culture of St. Petersburg. Positive experience of the country architecture preservation in Finland is stated.
\end{abstract}

Keywords-Russian Finland; Baltic coast; dacha architecture; cultural landscape; heritage; preservation and use

\section{INTRODUCTION}

The architecture of the country-seaside resort on the Baltic sea, which also includes the Russian coast of the Gulf of Finland, today appears as a special kind of heritage of the first third of the XX century, with its unique artistic features in the context of the Baltic region.The dacha heritage has been recently recognized as a phenomenon in the history of the cultural landscape of the suburbs of St. Petersburg, and in the history of Russian architecture of the Art-Nouveau era, and especially in recent years, in the context of cultural relations between St. Petersburg and Finland when the protection of this heritage at the Karelian isthmus has been realized asa common interest. This paper analyzes the

*The Reported study was Funded by Science and Technology Development State Program of the Russian Federation for years 2013-2020 Program of Fundamental Research of State Academies of Science for years 2013-2020, within the Program of Fundamental Researches of Ministry of Construction, Housing and Utilities of the Russian Federation and Russian Academy of Architecture and Construction Sciences; the Research Project 1.2.12. formation and peculiarities of the artistic features of the suburban dacha architecture of the so-called Russian Finland — the part of the Karelian isthmus until $1917^{1}$.

The dachas is more vulnerable than other types of the architectural heritage: it is the fragility of the wood which has been the most widespread construction material at that times, modern socio-economic conditions, as well as the problem of property and its legal status which play the most significant roles in this regard.

The huge number of architecturally brilliant dachas has been irretrievably lost, and not always because of the Second World War. Comprehensive studies, the most complete scientific and graphic documentation as well as the design practice play an important role in the process of dacha architecture restoration, preservation and protection.

The task of the comprehensive study of the dacha architecture of the Karelian isthmus coast and other suburbs of St. Petersburg in the broad socio-cultural context - as an architectural and artistic phenomenon of the Art-Nouveau era is acutely relevant in historical, cultural and academic and also in practical terms. Today there are buildings on the Karelian isthmus which represent the features of the cultural identity of the Baltic coast: the restaurant "Esplanade" in Vyborg (2016), the stage on the island of New Holland in St. Petersburg (2016), hotels and country estates in Sestroretsk (2015-2016).It confirms the relevance of the research for the modern architectural and urban planning practice. Thus, the value of this unique and fragile layer of heritage, which is rapidly disappearing before our eyes, is fixed in the public and professional consciousness and forms the understanding of the need to preserve and develop it ${ }^{1}$.

The Grand Duchy of Finland has been a part of the Russian Empire (1809 - 1917). Karelian isthmus to the Sestra (Sister) river have been the territory of Finland until 1939. 


\section{THE HISTORIOGRAPHY OF THE PROBLEM}

The representativeness of the dacha architecture of the national-romantic and other stylistic trends of the ArtNouveau era did not provide it with a worthy attention in the modern history of architecture.It has long remained outside the field of special comprehensive studies ${ }^{2}$. So it can be asserted, in spite of the publications of the last fifteen years: a pioneer article by I. J. Polenov [1], S. A. Simkina [2], V. I. Musaev, E. L. Alexandrova, V. M. Fedorov [3]; the articles of last five years by R. N. Garayeva [4], R. M. Dayanova [5], E. M. Travina [6] A. E. Bravo [7], S. Levoshko [8], O. B. Ushakova [9], and sections in fundamental studies on the Art-Nouveau architecture by V. G. Lisovsky [10] and B. M. Kirikov [11]. Special attention should be given to the dissertation work of O. I. Chernykh, which continues to be the only one since 1993, devoted to the theme of the dacha construction in the St. Petersburg province [12]. The main part of its content is devoted to the study of the development history of summer settlements of St. Petersburg province in the XVIII - early XX century, and the research of urbantypological and spatial-organizational problems of the environment, in the nature of which, in the author's opinion, regional characteristics and national preferences are reflected. In that work, the author carries out some very valuable conclusions. The B. Matveev's dissertation is devoted to the concept of the preservation and development of the historical environment of Sestroretsk, which remains to this day a kind of the reserve of the Karelian isthmus architecture, [13]. In 2016 the biographical reference book "Architects of the Karelian Isthmus" by E. M. Travina and S. S. Levoshko has been published for the first time. It includes brief biographical information about 76 architects, Russian, Estonian and Finnish, who have designed dachas and resort buildings in Russian Finland, dozens of whose names have been identified for the first time [14]. It is an indisputable fact that nowadays there are still many dachas indilapidated state, or whichhave been recently demolished, and their images are preserved only in photographs, have no attribution, so the painstaking attributive work must continue. This will allow for the clearer and deeper analysis of the phenomenon of dacha architecture of the Karelian isthmus.

The cultural and historical expertise, restoration projects studies, suburban architecture reconstruction projects also contribute to the preservation of individual dachas. However, all that measures clearly cannot be considered sufficient.

\section{The Stylistic InTERPRETATION OF THE DACHA ARCHITECTURE}

In the early XX century Russian Finland has become a popular holiday destination. The suburban area stretched along the Vyborg and the Primorsky highways, the Finland railway of St.Petersburg - Riihimaki (1870) and the coastal railway in Sestroretsk (1898). The recreational function of

\footnotetext{
Architectural and town planning studies would have been very difficult, and sometimes impossible without the preliminary work of local historiansE. A. Balashova, N. I. Rogaleva, A. E. Bravo, P. Korvekula, E. M. Travina to restore the names of the pre-revolutionary and pre-war owners of cottages, and the location of their plots on the Karelian isthmus.
}

Kivennapa parish in the Vyborg province has been determined during these yearsalong with a group of socalledsea villages which included Ollila, Kuokkala, Terijoki; "Kaunis and Toivola" villages has been formed. In the same period, the settlements of Kellomäki, Tarhovka, Aleksandrovskaya and Sestroretsk resort have been formed as well.

The mass character of the country development at the turn of XIX-XX centuries has made the dacha constructionan equal genre among the other ways of the architect's creativity expression. There have beencatalogs of thedacha model projects. However, the dacha architecture continued to be almost always unique, the only one of its kind, created by the will of the architect, considering the specifics of the place and the details of thecommission. The design of private dwellings provided the artist with exceptional conditions for the manifestation of self and approbation of the new techniques of the contemporary art practice.

The versions of the national-romantic Art-Nouveau of Finland, Northern (Scandinavian) and Southern (Latvia, Estonia) Baltic countries, the Northern Art-Nouveau of St. Petersburg have been naturally considered as the most suitable for the seasonal suburban dwelling in Russian Finland, which have had avividnatural and cultural identity.

As it is known, it was typical for the Art-Nouveau era to work in the national-romantic direction, and especially at the outskirts of the Russia Empire. The ideas of European Romanticism, as well as Finnish-Scandinavian Romanticism, have been very attractive for the Russian society.In the atmosphere of the artistic freedom of the transitional synergetic period, which the era of Art-Nouveau has represented, the fruitful artistic experience of Finland fell on the life-giving and omnivorous soil of Russian architecture. At the same time, St. Petersburg architects of Polish origin have been creating the projects of dachas in the national spirit of Poland - the so-called Zakopane style, and these projects have been highly appreciated by the Imperial Academy of arts.

The design of the dacha has been the part of the education as a course project at the Institute of Civil Engineers, which indicates the scope of the genre's direction. The brilliant national Romanticism of Finland has become a hobby not only for students, but also for architects who showed themselves in the construction of dachas. Its popularity and demand have been one of the results of fruitful interactions between Finnish and Russian cultures, first of all, St. Petersburg, at the turn of XIX-XX centuries [15].

Architects, intellectuals, businessmen have built cottages In Russian Finland according to the artistic preferences of their circle, and these preferences reflected the general trend for St. Petersburg, the main element in which has been the combination of Art-Nouveau stylistic features of FinnishScandinavian and Russian origins. The "Northern (Baltic) 
Theme" 3 has been the most favorite and attractive due to its identity to the cultural landscape of Russian Finland.

It is recognized, that the most impressive examples of the St. Petersburg dacha construction have been associated with the NorthernArt-Nouveau.First and foremost, this refers to the Karelian isthmus. Architects' private summer houses dachas, as a rule, are the most representative in terms of the art preferences of their circle, as in this case, the architectu present themselves: these are the villas of V. V. Suslov, G. V. Baranovsky, R. F. Melzer F. F. Postels, A. P. Vaitens, V. F. Haberzetel, S. G. Ginger, V. A. Kosyakov, V.V. Schaub, K. K. Schmidt, A. A. O1, F. A. Korzukhin, I. P. Gilev, K. H. Denisov, F. Lumberg and other St. Petersburg architects. Creative freedom and the relative ease of the dacha project approval allowed the artists - masters of fine art to try their efforts in the field of architecture. That gave birth to the artist's studios built according to the artists'own designs (the dachas of I. Repin, I. Vladimirov, V. Levi), as it has happened in the indigenous Finland, England or Belgium, and Russia, in the Moscow suburbs of Abramtsevo or Talashkino.

The estates oftheHvitträsk near Helsinki and SuurMerijokinear Vyborg (1901-1903), the house of Vittorp in Kirkkonummi and Minato in Espoo, built E. Saarinen, G. Gezelius and A. Lindgren, the house-studio of GallenKallela in Tarvaspää, Visavuoriestate of the sculptor Emil Wikström(late 1900s) and some others have become paradigmatic and received artistic and stylistic interpretations in the dachas and villas on the Karelian isthmus.

The Villa of Y. Gernandt - the "Cone Castle" in Kellomäki (mid-1900s, Komarovo, Bolshoyprosp., 11), the artist V. F. levy's dacha in Terijoki (1916, Zelenogorsk, Birch lane, D. 5) and the dacha of the architect F. Lumbergh (1910), now known under the name of the "Northern Riviera" sanatorium, in whose territory it is located, appear to be the most representative in this series. They have much in common with the Finnish style prototypes - thepicturesque multi-volume of large masses and especially "sculptural", faceted or round gnarled towers with tents and domes deeply embedded in the roof, as well as the shape of the roof itself, windows, the wall finishing and decorative treatment. The differences, perhaps, are the relatively calm terrain and the lack of rocky shores and cliffs.

The next group of dachas represents the architecture of karelianism. Those are, figuratively speaking, the "huts" of Russian Finland, in which the tradition of the national dwelling of Karelia and the Russian North is interpreted. The most prominent stylistic example here is the preserved dacha-workshop of the architect V. F. Haberzettel, which is located on the picturesque site In Kellomaki crossed by the stream (Komarovo, Kavaleriyskaya str., early 1900s). Therefore, the dacha was called "Oya" which meansthe stream. The lifestyle of that era, demanded the introduction of the artist to the origins of the national culture, and has

This unifying term refers to the regional community of nationalromantic variants of the Baltic region Art-Nouveau. It is proposed as an extension and refinement of the terminology dictionary of special regional studies. acquired complex forms, if the artist has been put to the cultural frontier - the Baltic frontier in this case. The architect hasn't worried about his Russian roots, but was inspired by the idea of assimilating with natural landscape and the cultural environment of Finland.

For the architect A. F. Korzukhin, who created the original design of the dacha in the Tyrisevävillage (self-name, the "Terem" or the "Black House", Ushkovo, Plazhevayastr., 14), the Norwegian folk tradition has clearly served as the basis for the house's artistic theme. Once again it is seen how different art schools in Northern Europe are closely intertwined on the Karelian isthmus.

E. F. Vazhevskaya's dacha of in the resort of Sestroretsk (Sestroretsk, Andreyevskaya str., 12) is another outstanding example of the Karelian isthmus dacha architecture. This work can also be attributed to the examples of the Northern Art-Nouveau of the mature period. It is a harmonious combination of Neo-Russian Style and Northern ArtNouveau, which has already well assimilated the experience of the painters of Russian and Finnish schools.

Another unusual "Palace" - the dacha of G. Muser in Terijoki (presumably by the architect V. V. Shaub, Zelenogorsk, Teatralnaya str., 9) adorns the suburban landscape of Russian Finland. Built in the early 1890s, it belongs to the early phase of romantic Art-Nouveau, the source of which has been the German national tradition. The facades have been decorated with wooden hinged structures typical for the sea-side resort of the southern Baltic coast in the late XIXcentury: Polish-Lithuanian Palanga, Sopot and Gdansk, Pärnu and Jurmala and other resorts. They, in turn, have been inspired by German samples published in catalogues widely known at that time.

The "Sofia's Hill" villa of S. A. of Glazov in Tyriseväbuilt by Finnish architect F. F. Maritz (circa. 1900's, not survived) is very different.The architecture of the villa is designed in the spirit of Scandinavian romanticism, and, according to the customer - in the "Norwegian style".

The famous dacha of M. S. Voronin in Metsäkylä (settlement Molodezhnoe) and the dacha of Kartavtsev "Morioki" inVammelsuu (architect E. P. Weinberg, settlement Serovo) withtheir huge expressive towers, have turned to the medieval Western European tradition. According to some researchers, the massive towers of the M. S. Voronin's dacha and others can be associated with religious buildings in Finland and the Baltic region.

The type of the "house with a tower" has been widespread on the Karelian isthmus, and in all suburbs of St. Petersburg.It represents a "freely growing up"but compact pictorial composition with the obligatory presence of the tower volume-the dominant of the composition, completing the expressive silhouette. There has been a variety of physical sizes, shapes and locations for such towers: the tower-belvedere, miniature towers as well ascentral and cornerones.

The certain specificity of the formation and artistic appearance of this special type of the house - the "house with a tower" - suggests that a new architectural style, as It 
was called by O. S. Chernykh — the "dacha style" has been born [16].The "style of villas" has been adopted in the mid1890 s in East Prussia as a self-name for country villas.

The architecture of the analyzed dachas is identical to the cultural tradition of the place - the Finnish coast of the Karelian isthmus, and wider - the entire Baltic coast.

In official documents the Finnish names have been reflected in the majority of dachas astoponyms and own names. Not to mention the fact that many of them have not been called "dachas" in a Russian way, but "villas": "Aida", "Ainola", "Lentella", "Nostra," etc. with the "genius loci" echoing in their naming.

\section{Current Practice of Preservation AND Use of DACHA HERITAGE IN ST. PETERSBURG AND FinLAND}

The analyzed stylistic samples of the dachas of the Karelian isthmuscoastal settlements (today it is theKyrortnyDistrict of St. Petersburg), consonant with the national-romantic searches of Finland and other Baltic countries, are in poor condition, others are in desolation or abandoned.

All Finnish estates preserved after the second world war are outstanding works of Finnish neo-romanticism kept in excellent technical condition. They are museumified, and serve as touristic objects. Most country houses of the turn of XIX - XX centuries in the Helsinki districts of Toolonlahti and Meilahti have survived. Some villas in Kaivopuisto are used as museums, including the Museum of Architecture. Villas and resort development (school, hotels, kursaals, villas) in Hanko in Finland (on-site survey of the author, December 2016) are in excellent condition. This holiday region has the status of outstanding site in the national register of cultural attractions of Finland (RKY, 2009). Thus, the historical environment is protected in a comprehensive manner. But there are also problems in Finland. Finnish architect M. Shalin, emphasizes that the villas on the Vartiosaariisland in the Eastern part of the Helsinki archipelago are mainly owned by the city, some of them are left without care, and their fate depends on the implementation of the project of the intensive use of the entire island, in which this vulnerable cultural landscape is supposed to be used for the construction of multi-storey houses, transport and social infrastructure for several tens of thousands of inhabitants. At the same time, the villas of Vartiosaari are the part of the suburban settlements network formed along the historical steamship routes in the vicinity of Helsinki. They are given the status of architectural and cultural landscape of national importance (RKY). The architect M. Shalin asks questions that equally concern us about our own country's heritage: what will remain from the unique architectural and natural features of that territory today? Can values be preserved? ${ }^{4}$

\footnotetext{
$4 \quad$ M. Shalin. On the historical villas on Vartiosaari and other
} Islands in the vicinity of Helsinki. Documentation and the assessment of cultural heritage as the part of urban planning: report at the Third RussianFinnish scientific and practical conference "Historical dacha settlements and resorts of the Gulf of Finland: problems of conservation and use". 2526 August 2018. Helsinki.
In St. Petersburg, a pressing problem is the development of the strategy for the conservation and the development of suburban heritage and its implementation program, the development of methods for managing this specific type of historical and cultural heritage.

Only the dacha of G. Muzer (Zelenogorsk, in emergency condition) from the whole range of magnificent dacha samples of the suburbs of St. Petersburg, a number of which have the status of cultural heritage, has been included in the selected list of "the Conception of the Preservation of the Monuments of Wooden Architecture and their Inclusion in the Cultural Circulation until 2025" (list No. 759-R. M., 2016). So there is no hope for the Federal Programs.

In this light, the draft Program (2013) proposed by the Council for the Preservation of Cultural Heritage under the government of St. Petersburg as a long-term target special Governor's Program for the preservation of the monuments of wooden architecture of St. Petersburg and its suburbs (part of which is the dacha architecture) for 2014-2016 is important.

It consists of 11 items, among which are:

- the monitoring of all wooden objects subject to state protection (including recently added) for the purpose of determination of their technical condition, measures for their support;

- the development of proposals on the system of benefits (tax and legal) for buyers (with mandatory encumbrance), owners and tenants engaged in repair and restoration work and at the same time additional sanctions against persons causing damage to the monuments;

- the initiation of relevant amendments to the law on the protection of the cultural heritage of St. Petersburg;

- the development of the subprogram of public-private partnership in relation to individual monuments of wooden architecture, mainly those that receive or already accommodate public functions;

- the introduction of a ban on the reduction of the protective status of the monuments of wooden architecture on the sale or after it;

- the preparation of the scientific catalog of all the existing monuments of wooden architecture of St. Petersburg and its suburbs with the simultaneous development of the subprogram of popularization of this type of monuments and methods of their preservation in the conditions of the city with the simultaneous generalization of foreign experience.

The government of St. Petersburg expressed its intention to promote it, because the situation is recognized as catastrophic. The pilot "Concept of Creation of Public Spaces on the Basis of Historical Wooden Buildings and the Development of Adjacent Territories in the Kyrortny District" assumed the main purpose to reconstruct and adapt emergency statedachasto socially significant functions.The 
architectural and artistic appearance of the building should consider the peculiarities of the cultural landscape.So far, there is no good example of the practical implementation of this project, which is in the stage of institutionalization. The recently published concept of Sestroretsk and the preliminary design solutions for a number of Sestroretskdachas with adaptation to social functions, unfortunately, do not stand up to professional criticism. There are a few good examples of the professionally done private restoration: The dacha of Yukhnevich (2018) and the Villa Reno ("Liteynaya chast91" architect R. Dayanov, 2018) in Komarovo.

Over the past five years, on the initiative of the of research group, consisting of architects and teachers in Komarovo, Zelenogorsk and Sestroretskthe summer studies, open-air and project practices of students of St. Petersburg are held as the part of the initiative project "Old dachas. The Disappearing Nature", focused on a comprehensive study and development of the fundamental design models for the rehabilitation of the summer housing of the Gulf of Finland. Thenumber of exhibitions of the results of these workshops have been held, they are being discussed, popularized, and presented in free access on the website www.terijoki.spb.ru. The database of the suburban development of the Karelian isthmus has been significantly broadened by the results of students' practices, as well as objects identified in the professional studies of measurements of dachas and resort buildingsof the city of Sestroretsk( head O. M. Runova, 1993).

In the summer of 2016, students of St. Petersburg State University have held a measurement and architectural design practice in Zelenogorsk. They performed hand-made architectural measurements of the objects from the list proposed by the administration of the Kyrortny District for the renovation in the city of Zelenogorsk and the surrounding area - five objects in total. Thepriority has been given to the objects of an undoubted historical, architectural and cultural value. They have been defining the architectural features of the cultural landscape of the Zelenogorsk suburban district since the beginning of the XX century, but are in unsatisfactory, and often, in an emergency condition. The proposals for architectural planning and functional solutions (several options for each structure) have been developed.Thus, the experience of historical country buildings preservation with the correct and acceptable level of transformation in order to adapt to modern functions and increase attractiveness for potential investors crystallizes in the architectural youth.

The experience of neighboring Finland shows that a long-term state program should be adopted to improve the state of historical areas with dacha architecture of the coast of the Gulf of Finland, as well as other suburbs of St. Petersburg. Its "formula for success" may not be as widely known as we would like it to be, but it is not a problem for a specialist to study it. However, it should not be overlooked that such programs have been adopted (and are being successfully implemented) in Finland as the result of the strong awareness of the value of this development by the general public, which has taken vigorous actions in to preserve and promote the country's once unrecognized cultural heritage.

\section{CONCLUSION}

The dacha heritage of the Karelian isthmus, which has belonged to the Grand Duchy of Finland in the Russian Empire until 1917 - the so-called Russian Finland, has an exceptional originality. On the one hand, this is a unique phenomenon for the history of Russian architecture, on the other - created in its majority by St. Petersburg architects, it harmoniously blended into the cultural landscape of the coasts of the Gulf of Finland and the Baltic sea. The comparative architectural and artistic analysis of the buildings of this genre performed by the world-class Finnish masters shows that they have been a source of inspiration for Russian architects who managed to melt the artistic findings in the national-romantic way and create their own masterpieces. The idea is to consider this heritage as a "sharedcultural heritage" with Finland.

The catastrophic situation of the dacha architecture of St. Petersburg suburbs, and the coast of the Karelian isthmus in particular, considered in detail in this work, obliges to the urgent development of a specialized government program for the preservation and use of this valuable layer of the material heritage of the Art-Nouveau era, which is now disappearing before our eyes.The so-called"shared built heritage" should be treated with a deep understanding of the uniqueness of the situation and the touristic and economic potential of the territory. There is a scientific Committee SBH (Shared Built Heritage) in ICOMOS, which has methodological developments and practical experience around the world. Neighboring Finland has its own rich experience in the field of preservation and use of wooden and stone architecture of this genre, which, if desired, can be used in the management of this heritage.

\section{REFERENCES}

[1] I. Y. Polenov. Wooden Architecture of the Southern Coast of the Gulf of Finland 1860-1917 // Questions of History, Theory, and Practice of Architecture, L., 1985, p. 108-116.

[2] S. A. Simkina. Art-Nouveau Dachasof the Northern Coast of the Gulf of Finland //Monuments of History and Culture of St. Petersburg, SPb., 1997, Vol. 4, p. 335-349.

[3] V. I. Musaev. Russian Dachas on the Karelian Isthmus in the late XIX-early XX century // The History of St. Petersburg, 2006, No. 4, p. 43-47.

[4] E. L. Alexandrova, V. M. Fedorov. Art-Nouveau Dachas in Sestroretsk and its Vicinities // TheHistory of St. Petersburg, No. 1-3, 2008.No. 1, p. 25-28; No. 2(42), p. 24-28; No. 3, p. 88-90.

[5] R. N. Garaeva. The Northern Art-Nouveau Architecture of the Karelian Isthmus // KurortnyDistrict, Pages of history, Vol. 3,SPb, 2007, p. 11-25

[6] R. M. Danov. On the Architecture of Kellomyaki-Komarovo //Komarovo-Kellomyaki. Articles and Memories,SPb., 2010, p. 55-59.

[7] E. M. Travina. Komarovo Art-Nouveau dachas // Kurortny District. Pages of History, Vol. 6, SPb., 2011, p. 116-132.

[8] S. S. Levoshko. The Cultural Landscape of the Komarovo village as the Subject of Protection // Architecture of the Art-NouveauEra in the Baltic region, Theses of the International Scientific Conference, SPb., 2013, p. 58-60. 
[9] A. E. Bravo. Vasily Filippovich Levi's Dacha, Zelenogorsk. Berezoviy lane 5 // Smolyanoy Put,SPb., 2014, Vol. 1, p. 47-52.

[10] E. M. Travina, O. B. Ushakova. Architect GavriilVasilievich Baranovsky and his Villa - the "Harp" // Smolyanoy Put. SPb., 2014, Vol. 1, p. 47-52.

[11] V. G. Lisovsky. The"National style" in the Architecture of Russia. M., 2000; Russian Architecture of the XVIII - beginning of XX century. The Search for the National Style, M., 2009, p. $401-404$.

[12] B. M. Kirikov. Architecture of St. Petersburg's Art-Nouveau. Mansions and Dachas. SPb., 2003; Architecture of St. Petersburg in the late XIX-early XX century. Eclecticism. Art-Nouveau, Neoclassicism, SPb., 2006, p. $297-230$.

[13] O. I. Chernykh. Dacha Construction of the St. Petersburg Province of the XVIII - early XX centuries,A dissertation for the degree of the candidate of architecture, $\mathrm{SPb} ., 1993$, in 2 volumes.

[14] B. M. Matveev. Historical-Theoretical and Scientific-Practical Development of Urban Planning and Regulation of the Historical Urban Environment of the Sestroretsk Architectural and Landscape Complex. A dissertation for the degree of the candidate of architecture, $\mathrm{SPb}, 2013$.

[15] E. M. Travina, S. S. Levoshko. Architects of the Karelian isthmus. Volume One. From Solnechniy to Molodezhniy (from Ollila to Metsäkylä) 1880-1993. Biographical Reference, SPb.: OOO "'Ostrov" Publishing Center, 2016, p. 208.

[16] E. G. Soini. Finland in Russian art. 1890-2010, Petrozavodsk, 2013, p. 170 .

[17] O. I. Chernykh. Dacha construction of the St. Petersburg Province of the XVIII - early XX centuries]. A dissertation for the degree of the candidate of architecture, SPb., 1993, Vol.1, p. 90, 92. 